\title{
Drónok és más eszközök közötti interakciók, valamint a képi adattovábbítás fejlesztésére vonatkozó kompetenciák ${ }^{1}$
}

\section{TÓTH Veronika Zsófia ${ }^{2 \oplus}$}

\begin{abstract}
A pilóta nélküli repülő szerkezetek (drónok) lehetővé teszik az adatgyújtést olyan területeken és időben, amelyek továbbra is elérhetetlenek a hagyományos távérzékelő platformok számára. A technikai fejlödésnek köszönhetően alkalmazási körük egyre tágul, és az egyes eszközök specifikálódnak. Az alkalmazás fó limitáló tényezői a képtovábbítás és a drón, valamint más eszközök közötti kapcsolat (például a drón és az irányító kapcsolata, dróndrón kommunikáció). A tanulmány célja e technológiák jelenlegi helyzetének és a jövőben lehetséges fejlesztési irányok bemutatása.
\end{abstract}

Kulcsszavak: drón, képi adattovábbítás, interakció

\section{Bevezetés}

A tanulmány célja a drónok és más eszközök, mint például járművek, földi telepítésű eszközök, illetve más drónok közötti interakciók és a képi továbbítás fejlesztésére vonatkozó kompetenciák vizsgálata. A drón vagy UAV (Unmanned Aerial Vehicle, pilóta nélküli repülő eszköz) olyan repülőeszköz, amely valamilyen ön- vagy távirányítással (vagy ezek kombinációjával) rendelkezik, emiatt fedélzetén nincsen szükség pilótára. A technológiai fejlődés (finommechanika, mikroelektronika) és a csökkenő árak hatására a drónok az átlagember számára is elérhető eszközökké váltak, így már nem kizárólag hozzáértő, képzett pilóták üzemeltetik őket. Az egyre nagyobb hatótávolság, megnövekedett üzemidő, folyamatosan fejlesztett navigációjú drónok képés hangrögzítő rendszerekkel felszerelve egyre komolyabb biztonságtechnikai kockázatot is jelentenek. Az eszközök kommunikációjának és adatrögzítő eszközökkel való felszereltségének kiemelt fontosságára az Európai Unió is felfigyelt. A 2019-ben elfogadott, a drónok használatára vonatkozó egységes európai törvénycsomag,

A mủ az NKFIH-866-5/2020 iktatószámú Megállapodás alapján az NKFI Hivatal és az Innovációs és Technológiai Minisztérium által biztosított támogatással, a Biztonsági Technológiák Nemzeti Laboratórium finanszírozásával valósult meg.

2 Tóth Veronika Zsófia, Magyar Agrár- és Élettudományi Egyetem Kertészettudományi Doktori Iskola, doktorandusz. Veronika Zsófia Tóth, Hungarian University of Agriculture and Life Sciences, Doctoral School of Horticultural Sciences, PhD student. E-mail: tovsaat@gmail.com 
a Commission Implementing Regulation (EU) 2019/947³ az egyes múveleti kategóriák meghatározásakor a hatótávolságot (amely a drón és a kontroller kommunikációjának függvénye) és az adatrögzítővel való felszereltséget is figyelembe vette. A valós idejű, nagy felbontású képtovábbítás nélkülözhetetlen eleme a biztonságos navigációnak és a precíz küldetés-végrehajtásnak, ugyanakkor a jelenlegi kereskedelemben kapható drónok gyenge interferenciagátló képességgel és jelentős késleltetéssel rendelkeznek, így a videó megbízhatósága nem garantálható. Jelen munka célja a jelenleg használatos kommunikációs és képtovábbítási technológiák ismertetése, a fejlesztési kompetencia áttekintése.

\section{A drón és az irányító kommunikációja}

A drón átviteli rendszere a drón és a vezérléshez használt távirányító vagy intelligens eszköz közötti kommunikációt biztosítja. Az átviteli rendszer befolyásolja a drón hatótávolságát, a videóátvitelt, az átviteli késést és az elérhető vezérlő frekvenciákat. Jelenleg három módszer elterjedt a drónok irányításában: a rádióhullám, 4G-hálózat vagy közvetlenül ember általi irányítás.

\subsection{Rádióhullámokkal történö irányítás}

A rádióhullámokkal történő irányítás alapvetően négy módon valósulhat meg: Bluetooth, WiFi, Lightbridge és OcuSync. Az egyes technológiák összehasonlítása és főbb karakterisztikája az 1. táblázatban látható.

\section{1. táblázat: A távvezérlō és a drón közti kommunikáció lehetőségei}

\begin{tabular}{|c|c|c|c|c|}
\hline & Bluetooth $^{4}$ & $\mathbf{W i F i}^{5}$ & Lightbridge $^{6}$ & OcuSync $^{7}$ \\
\hline $\begin{array}{l}\text { Meghatá- } \\
\text { rozás }\end{array}$ & $\begin{array}{l}\text { Rövid hatótávú, } \\
\text { vezeték nélküli, adat- } \\
\text { cseréhez használt, } \\
\text { rövidhullámú rádió- } \\
\text { frekvenciát alkalma- } \\
\text { zó megoldás. }\end{array}$ & $\begin{array}{l}\text { Adatcseréhez hasz- } \\
\text { nált, vezeték nélküli, } \\
\text { rádióhullámokkal } \\
\text { történő kommuniká- } \\
\text { ciót (WLAN) meg- } \\
\text { valósító szabvány, } \\
2,4 \text { vagy } 5,8 \text { GHz-n } \\
\text { működik. }\end{array}$ & $\begin{array}{l}\text { Adatcseréhez hasz- } \\
\text { nált, vezeték nél- } \\
\text { küli összeköttetés, } \\
2,4 \text { vagy } 5,8 \mathrm{GHz}-n \\
\text { múködik. }\end{array}$ & $\begin{array}{l}\text { A legnagyobb ható- } \\
\text { távolságot biztosító } \\
\text { rádióhullámmal } \\
\text { múködő adatcseréhez } \\
\text { használt technológia. }\end{array}$ \\
\hline
\end{tabular}

3 Commission Implementing Regulation (EU) 2019/947 of 24 May 2019 on the rules and procedures for the operation of unmanned aircraft. C/2019/3824.

4 Angela M. Lonzetta et al.: Security Vulnerabilities in Bluetooth Technology as Used in IoT. Journal of Sensor and Actuator Networks, 7. (2018), 3. 28.

DJI transmission systems - Wi-Fi, OcuSync \& Lightbridge. Heliguy, 2018. augusztus 20.

DJI Lightbridge 2Specs: www.dji.com/hu/lightbridge-2/info

Lásd: https://store.dji.bg/en/blog/what-is-dji-ocusync-and-how-does-it-work 
TÓTH Veronika Zsófia: Drónok és más eszközök közötti interakciók, valamint a képi adattovábbítás...

\begin{tabular}{|l|l|l|l|l|}
\hline & \multicolumn{1}{|c|}{ Bluetooth $^{4}$} & \multicolumn{1}{|c|}{ WiFi $^{5}$} & \multicolumn{1}{c|}{ Lightbridge $^{6}$} & \multicolumn{1}{c|}{ OcuSync $^{7}$} \\
\hline $\begin{array}{l}\text { Ható- } \\
\text { távolság }\end{array}$ & $10-50$ méter & $500-2000$ méter & 5000 méter & $7000-10000$ méter \\
\hline $\begin{array}{l}\text { Adatátvite- } \\
\text { li sebesség }\end{array}$ & $1-3 \mathrm{MB} / \mathrm{s}$ & $20-30 \mathrm{MB} / \mathrm{s}$ & $30 \mathrm{MB} / \mathrm{s}$ & $40 \mathrm{MB} / \mathrm{s}$ \\
\hline Alkalmazás & $\begin{array}{l}\text { Játékkategóriás } \\
\text { eszközök esetén }\end{array}$ & $\begin{array}{l}\text { Középkategóriás } \\
\text { eszközök esetén }\end{array}$ & $\begin{array}{l}\text { Professzionális dró- } \\
\text { nok esetén }\end{array}$ & $\begin{array}{l}\text { Professzionális dró- } \\
\text { nok esetén }\end{array}$ \\
\hline
\end{tabular}

Forrás: a szerző szerkesztése

Amint az az 1. táblázatból leolvasható, a lényegi különbség a hatótávolságnál és az adatátviteli sebességnél figyelhető meg. A Bluetooth néhány tíz méteres hatótávolságával szemben az OcuSync 7-10 kilométeres hatótávolsággal rendelkezik, az adatátviteli sebesség pedig a Bluetooth 1-3 Mb/s-mal szemben az OcuSync-nél $40 \mathrm{MB} / \mathrm{s}$. Ezenkívül a Lightbridge és az OcuSync a WiFi-nél jóval kevésbé érzékeny az interferenciára, így stabilabb működést és biztonságosabb repülést tesz lehetővé, még erős rádiójelekkel terhelt környezetben is stabil múködést biztosít.

\subsection{Mobilhálózaton keresztüli irányítás $(4 G, 5 G)$}

A drónvezérlés új kommunikációs fajtája a celluláris, 4. és 5. generációs mobilhálózaton keresztüli irányítás. A mobilhálózatok alkalmazásának nagy előnye, hogy ahol van lefedettség, a drón bárhol képes repülni. Ez jelentős előrehaladás lenne a hagyományos módszerek által biztosított maximum 10 kilométeres hatótávolsághoz képest, tekintve a kiterjedt mobiltelefonos lefedettséget. A technológia fejlesztésének érdekében drónalapú kísérleti platformot fejlesztettek ki a 4G-hálózat értékelésére a levegő-föld adatátvitelhez. Az eredmények azt mutatják, hogy a 4G-hálózat képes jó csatlakozással és alacsony adatveszteséggel biztosítani a kommunikációt. ${ }^{89}$ A 4G-hálózat alkalmazásának ugyanakkor korlátai is vannak. Az adatveszteség jelentősen megnő, ha a jelerősség csökken és meg kell felelnie az árnyékolás és a többutas terjedés kihívásának. Bár a mobilhálózat lefedettsége igen kiterjedt, éppen bizonyos kritikus területeken nem megfelelő. Ilyen területek jellemzően az országhatárok. Az árnyékjelenség tovább képes csökkenteni a jelerôsséget, például amikor a vezeték nélküli jelnek át kell haladnia az akadályokon (például falakon). ${ }^{10} \mathrm{Az}$ irányítás technikai feltételeire, illetve a minél jobb hatótávolság elérésére kereste a választ egy 2021-ben megjelent tanulmány. A 120 méteres repülési magasság bizonyult optimálisnak, mivel alacsonyabb magasságon az objektumok (épületek, fák) nem árnyékolják a jelet. A 4G-s irányítás létrejöttéhez extra mikrokomputert, modemet

8 Liqi Chen et al.: 4G Network for Air-Ground Data Transmission: A Drone based Experiment. In 2018 IEEE International Conference on Industrial Internet (ICII) 2018. 167-168.

9 Robert Guirado et. al.: StratoTrans: Unmanned Aerial System (UAS) 4G Communication Framework Applied on the Monitoring of Road Traffic and Linear Infrastructure. Drones, 5. (2021), 1. 10.

10 Qazi, Sameer - Ali S. Siddiqui - Asim I. Wagan: UAV Based Real Time Video Surveillance over 4G LTE. In 2015 International Conference on Open Source Systems \& Technologies (ICOSST) 2015. 141-145. 
és SIM-kártyát szükséges a drónba építeni. A repülési területet lefedő 4G-hálózati antenna olyan magasságban található, amely meghaladja a drón felső magasságát, az antenna kiváló jelet biztosít. Magyarországon kutatások folynak egy pilóta nélküli földi jármű használatáról a határ biztosítása érdekében. A spanyol Robotnik cég által gyártott jármű önjáró, képes hordozni és működésbe helyezni egy kis drónt. Nincs további információ, hogy ez a drón milyen irányítási rendszerrel működik. ${ }^{11}$ A 4G-mobilhálózatok széles körű lefedettséget kínálnak, az adatátviteli sebesség elfogadható bizonyos drónrendszerek számára, de nem elégséges például a fejlett, autonóm módon szerveződő több drónt magában foglaló rendszerek számára, amelyek nagy sebességű valós idejű kommunikációt és feldolgozási kapacitást igényelnek. Ehhez továbbfejlesztett mobil szélessávra, megbízható, nagyon alacsony késésú kommunikációra, hálózati szeletelésre és az úgynevezett mobile edge computing-ra (peremhálózati számítástechnika) van szükség. Egy másik tanulmány szintén megfelelőnek találja a 4G-vel megvalósuló drónirányítást, a nagy átviteli sebességet és nagyon kicsi késleltetést igénylő feladatokhoz a 4G-hálózat fejlesztését tartja szükségesnek. ${ }^{12}$ Ezt sokan már az 5G-hálózat keretein belül látják megvalósulni. ${ }^{13}$

$\mathrm{Az} 5 \mathrm{G}$ az ötödik generációs mobilhálózat, amelynek legfontosabb kihívása mindenütt elérhető kapcsolat biztosítása a különféle típusú készülékekhez. A pilóta nélküli légi jármúvek várhatóan fontos elemei lesznek a közelgő fejlesztésnek, amelyek potenciálisan megkönnyítik a vezeték nélküli sugárzást, és támogatják a nagy sebességú adásokat, a megbízható, alacsony késésű kommunikációt, a network slicing és a mobil peremhálózati számítástechnikai megoldásokat. ${ }^{14}$ Egy 2020-ban publikált tanulmányban ${ }^{15}$ azt a következtetést vonták le, hogy az átlagos magasságban repülő drón akár több száz Mbit/sec sebességú fogadásra is képes, ami a legtöbb alkalmazáshoz, múvelethez elegendő. A transzmissziós rendszernek nagy szerepe van az energiamegtakarításban is, szimulációban sikerült $50 \%$ energiát megtakarítani transzmissziós ütemezési séma felhasználásával. ${ }^{16}$ Ugyanakkor az 5G-s drónirányítási rendszer még fejlesztésre szorul, ugyanis az 5G bázisállomással való kapcsolat jelenleg még nem tartható fenn az egész repülés alatt, a kapcsolat viszszaáll a 4G-hálózatra. 2020 novemberében a Vodafone és az Ericsson sikeresen tesztelték az 5G-drónok légi folyosóit a Vodafone 5G mobilitási laboratóriumában, Aldenhovenben, Németországban, amivel a két vállalat egy lépéssel közelebb került

11 P. Burt - J. Frew: Crossing A Line: The Use of Drones to Control Borders. Drone Wars, 2019; Víz alatti drónt is bevetnének a határvédelemben. Privátbankár, 2019. augusztus 27.

12 Muhammad A. Zulkifley et al.: Mobile Network Performance and Technical Feasibility of LTE-Powered Unmanned Aerial Vehicle. Sensors, 21. (2021), 8. 2848.

13 Raheeb Muzaffar et al.: First Experiments with a 5G-Connected Drone. In Proceedings of the $6^{\text {th }}$ ACM Workshop on Micro Aerial Vehicle Networks, Systems, and Applications 2020. 1-5.

14 Bin Li - Zesong Fei - Yan Zhang: UAV Communications for 5G and Beyond: Recent Advances and Future Trends. IEEE Internet of Things Journal, 6. (2018), 2. 2241-2263; Muzaffar et al. (2020): i. m. 1-5.

15 Muzaffar et al. (2020): i. m. 1-5.

16 Kai Li et al.: Energy-Efficient Cooperative Relaying for Unmanned Aerial Vehicles. IEEE Transactions on Mobile Computing, 15. (2015), 6. 1377-1386. 
az 5G-drónok valós használatának lehetővé tételéhez. ${ }^{17}$ Egy 2017-es tanulmány új lehetőséget vetett fel a lefedettségi problémák kiküszöbölésére. A 4G- vagy 5G-állomások miniatürizálásával azok felszerelhetők a drónra, lehetővé téve, hogy bármilyen nehezen elérhető területre el tudják szállítani, ahol a hagyományos állomások telepítése nehéz vagy költséges. ${ }^{18} \mathrm{~A}$ Nokia már kifejlesztett egy miniatürizált, csak 2 kg súlyú 4G-bázisállomást, amelyet sikeresen felszereltek egy kereskedelmi quadkopterre, hogy lefedettséget biztosítson Skócia távoli területén. ${ }^{19} \mathrm{E}$ mobil bázisállomások előnye, hogy bárhol bevethetők anélkül, hogy a földi közlekedési viszonyok korlátoznák. ${ }^{20}$ Ezenkívül a drónok megváltoztathatják pozíciójukat a körülményeknek megfelelően, hogy elkerüljék az interferenciát. ${ }^{21} \mathrm{~A}$ drónok vezérlése az utóbbi években nagy változáson ment át. A kezdetben egyirányú távvezérlést felváltotta a kétirányú kommunikáció, ahol már a pilóta is visszakapott adatokat a repülőeszköz felől. Az évtizedekig rendszeresített szimplex VHF-sávban múködő, impulzusszélesség-modulált (PWM) kommunikációs kapcsolat az alacsony vivőfrekvencia és a kevés számú csatorna miatt zavarérzékeny volt, ha több RC- (Radio Controlled) modell volt a levegőben. A 2,4 GHz-es ISM-sávban működő digitális úgynevezett frekvenciaugrás (FSHH) kommunikációnál nemcsak a pilóta képes navigációs utasításokat adni a drón irányába, hanem a drón is visszaküldi a telemetriaadatokat és a fedélzeti kamera képét a pilóta felé. Ezáltal folyamatosan követheti a pontos GPS-koordinátákat, az akkumulátor töltöttségi szintjét vagy más érzékelők által küldött adatokat. A harmadik generációs távirányítás már nem a megszokott pont-pont kommunikáció elven múködik, hanem a meglévő mobiltelefon-hálózatot használja fel (4G, 5G). ${ }^{22}$

\subsection{Drón és humán interakció}

Ezek az innovatív módszerek, amelyeket összefoglaló néven természetes felhasználói interfészeknek (natural user interfaces, NUI) neveznek, lehetővé teszik a felhasználók interakcióját a drónokkal gesztus, beszéd, tekintet, érintés, sőt agy-számítógép interfészek (BCI) segítségével. ${ }^{23}$ A természetes felhasználói felületek lehetővé teszik a nem szakértő felhasználók számára, hogy rövidebb időn belül irányítsák

\footnotetext{
Dan Oliver: 5G drones: everything you need to know. 5Gradar, 2021. augusztus 24.

18 Azade Fotouhi - Ming Ding - Mahbub Hassan Dronecells: Improving 5G Spectral Efficiency Using Drone-Mounted Flying Base Stations. 2017.

19 Mary-Ann Russon: Nokia and EE trial mobile base stations floating on drones to revolutionise rural 4G coverage. International Business Times, 2016. augusztus 15.

20 Jiangbin Lyu et al.: Placement Optimization of UAV-Mounted Mobile Base Stations. IEEE Communications Letters, 21. (2017), 3. 604-607.

21 Xiaohui Li: Deployment of Drone Base Stations for Cellular Communication without Apriori User Distribution Information. In $201837^{\text {th }}$ Chinese Control Conference (CCC) 2018. 7274-7281.

22 Hell Péter: Drón-rendszerek biztonságos kommunikációja. Köztes-Európa, 8. (2016), 1-2. 169-175.

${ }^{23}$ Jessica R. Cauchard et al.: Drone \& Me: An Exploration into Natural Human-Drone Interaction. In Proceedings of the 2015 ACM International Joint Conference on Pervasive and Ubiquitous Computing. 2015. 361-365.
} 
a drónokat. Csökken tehát a képzési időszak, a munkaterhelés és az eszköz lezuhanásának esélye. A gesztusokkal történő irányítás eszköze jellemzően a Kinect érzékelő, a Leap Motion érzékelő és a BioSleeve-vel érzékelt elektromiográfiás jelekkel. A hanggal történő irányítás a gesztusvezérléshez hasonlóan késleltetést okozhat, ezenkívül a gyorsan forgó légcsavarok hangos zajt hoznak létre. Az agy-számítógép interfész eszközök széles potenciállal rendelkeznek. Az interfészek két csoportba sorolhatók, hagyományos ember-számítógép interfészek és közvetlen interfészek. ${ }^{24}$ 2010 óta a kutatók a BCI (brain-computer interface) használatát vizsgálták merevszárnyú drónok esetén, 2013-ban pedig megjelent az első agyvezérelt multirotoros drón projekt. Leggyakrabban EEG-s (elektroenkefalográfiás) headsetet viselve történik a drónok irányítása, amely méri az agy elektromos aktivitását a fejbőrön, amely gépi tanulási algoritmusok segítségével dekódolódik. ${ }^{25} \mathrm{~A}$ nem invazív agy-számítógép interfész (BCI) dekódolja az agyjeleket a felhasználói szándék megértésének céljából. Már létrejött az agy-drónraj interfész prototípusa is, amelynek segítségével drónrajt lehet irányítani az agytevékenységgel. A tanulmány bizonyította a módszer alkalmazhatóságát szimulációs környezetben. A négy fő parancs a drónraj irányításánál a lebegés, leválás, szétszóródás és egyesülés. A tanulmány konklúziója szerint az EEG osztályozási teljesítménynek magasabbnak kell lennie, és több parancsot kell lefednie. Ezért a mély tanulási megközelítés alkalmazható a rajok irányítására szolgáló rendszer fejlesztésében. ${ }^{26}$

\subsection{Drónok kommunikációja másik drónnal}

A drónraj drónok egysége, amelyek képesek valamely feladat vagy feladatsor végrehajtására, amelynek során önszerveződően működnek. Az ELTE Biológiai Fizika Tanszék és az MTA-ELTE Biológiai és Statisztikus Fizikai Kutatócsoport drónrajos kutatási eredményei 2014-ben járták be a világot először. ${ }^{27}$ A Vicsek Tamás által vezetett kutatócsapat készítette el a világ első tíz egyedből álló kültéri önszerveződő kvadrokopterflottáját. A kutatóknak terepen 30 valósághű szimulációban, akár ezer nagy sebességú drón szoros együttmúködését sikerült ütközésmentesen megvalósítani akadályokkal terhelt környezetben. ${ }^{28}$ A drónraj működéséhez egyszerre szükséges a globális együttmozgás képessége, ugyanakkor minden eszköznek szükség esetén

24 Ran Jiao et al.: An Intuitive End-to-End Human-UAV Interaction System for Field Exploration. Frontiers in Neurorobotics, 13, (2020), 117.

25 Dante Tezza - Marvin Andujar: The State-of-the-Art of Human-Drone Interaction: A Survey. IEEE Access, 7. (2019), 167438-167454; Iuliana Marin - Missar J. H. Al-Battbootti - Nicolae Goga: Drone Control Based on Mental Commands and Facial Expressions. In $202012^{\text {th }}$ International Conference on Electronics, Computers and Artificial Intelligence (ECAI) 2020. 1-4.

26 Ji-Hoon Jeong et al.: Towards Brain-Computer Interfaces for Drone Swarm Control. In $20208^{\text {th }}$ International Winter Conference on Brain-Computer Interface (BCI). 2020. 1-4.

27 Gábor Vásárhelyi et al.: Outdoor Flocking and Formation Flight with Autonomous Aerial Robots. In 2014 IEEE/RSJ International Conference on Intelligent Robots and Systems 2014. 3866-3873.

28 ELTE: Beszélgetö drónrajok, összehangolt repülés (2018. július 18.). 
gyorsan képesnek kell lennie saját pályájának, mozgásának módosítására. Egy együtt mozgó csoport kihasználhatja a rend és a fogékonyság egyidejűségét, ha finomhangolja belső paramétereit. Hogy mennyi befolyása van az egyes eszközöknek saját, illetve szomszédaik sebességére, azt az úgynevezett „akarati tényező” (will factor) határozza meg. A hagyományos drónrajos repülések esetén egy földi irányítórendszer irányítja valamennyi drónt. A számítógép rádió adó-vevővel van felszerelve, amely telemetrikus adatokat küld és fogad a dróntól, tartalmazza az olyan információkat, amelyeket az érzékelőkből gyűjtöttek (például sebesség). Hagyományosan ezek az adó-vevők rádiófrekvenciás sávokat használnak (például $900 \mathrm{MHz}$ ) az információk küldéséhez és fogadásához. Magasabb autonómia esetén a drónok önálló döntést is hozhatnak. ${ }^{29} \mathrm{~A}$ drónok autonómiájának hat szintje különböztethető meg, a nulla autonómia és a teljes autonómia között. A nulla autonómiával rendelkező drónok esetén a mozgás, feladat-végrehajtás teljesen ember által kontrollált, míg a teljes autonómia esetén a döntéseket algoritmusok hozzák meg. A döntéshozatali paradigma három szakasza: adatok, vezérlés és végrehajtás. A szenzorok biztosítják a nyers adatokat, mint például a GPS, a légsebességmérő, az akusztikus érzékelők vagy a kamerák. A vezérlés két alfolyamata az észlelés és a tervezés. Az észlelés során a bizonytalan adatok hasznos információvá alakulnak. A tervezés során ezen adatok alapján létrejön a döntés, amely a küldetés végrehajtását segíti. A végrehajtás során a döntés kivitelezése és a küldetés végrehajtása zajlik. Az autonóm kiberfizikai rendszerek döntéshozó paradigmákat alkalmaznak az adat, kontroll és feldolgozás területén. A drónrajok alkalmazásának előnye az idő- és munkamegtakarítás, kevesebb emberi erőforrás alkalmazása és költségmegtakarítás. ${ }^{30} \mathrm{Az}$ UAV-k az együttműködés és a kommunikáció során kihívásokkal küzdenek. Ilyen a nagy sebesség, amikor is a kommunikációs kapcsolatok nem tudják irányítani az útválasztási mechanizmust befolyásoló folyamatokat. A gyakori topológiai változtatások is hatással vannak az útválasztási mechanizmusra. A drónok közötti kommunikációs hálózat befolyásolja a szolgáltatás minőségét, és szembesül a teljesítmény problémájával. Az energia felhasználásának korlátozása és optimalizálása érdekében szükség van energiahatékony mechanizmusokra. ${ }^{31}$

\section{Drón és egyéb földi eszközök kommunikációja}

A drónok és egyéb földi eszközök kommunikációja kibővíti, szélesíti a drónok alkalmazásának lehetőségeit, mint például a gyors újratöltés vagy mobil bázisállomások

29 Boldizsár Balázs - Gábor Vásárhelyi - Tamás Vicsek: Adaptive Leadership Overcomes Persistence-Responsivity Trade-Off in Flocking. Journal of the Royal Society Interface, 17. (2020), 167. 20190853.

30 Mitch Campion - Prakash Ranganathan - Saleh Faruque: A Review and Future Directions of UAV Swarm Communication Architectures. In 2018 IEEE International Conference on Electro/Information Technology (EIT). 903908.

31 Haque Nawaz - Husnain M. Ali - Asif A. Laghari: UAV Communication Networks Issues: A Review. Archives of Computational Methods in Engineering, 28. (2021). 1349-1369. 
létesítése. A drónok repülés közbeni vagy töltőállomásokkal történő gyors újratöltése a korábbinál hatékonyabb müvelet-végrehajtást tesz lehetővé. A drón által hordozott mobil bázisállomások pedig lehetővé teszik az internet-hozzáférést olyan helyeken is, ahol nincs kiépített infrastruktúra vagy katasztrófahelyzet miatt ideiglenesen nem használható.

\subsection{Drónok és töltöállomás összeköttetése}

A drónok és töltőállomásaik közötti összeköttetés létesítésére több módszer is rendelkezésre áll. A legelterjedtebb a hagyományos, akkumulátoros megoldás, jellemzően töltőkábellel történő töltéssel. Ez a módszer azonban nem nyújt lehetőséget tartós repülésre, a kis energiasűrúségből eredően. Az akkumulátoros drónok támogatására lehetőséget kínálnak a vezetékes drónok, a töltőállomások és a repülés közbeni lézersugaras töltés. A töltőállomások dokkoló platformjainak ellátását nagy kapacitású akkumulátorok, távvezetékek vagy napelemek biztosítják. A lézersugaras töltés előnye, hogy vezeték nélküli módszer, és a drón repülés közben is töltődhet. A vezetékes drónok optikai kábelei sok kilowatt áram továbbítását teszik lehetővé nagy intenzitású fényt alkalmazva. A hibrid drónok esetén az akkumulátor mellett üzemanyagcellák, napelemek vagy szuperkondenzátorok egészítik ki a rendszert. ${ }^{32}$ A graféntechnológia a drónok területén nagy hatást fejthet ki. Az első grafén bevonatú drón a Juno, amelyet a University of Central Lancashire mutatott be 2018-ban. 3,5 méteres szárnyakkal a grafén bevonatú, merevszárnyú eszköz 17\%-kal könynyebb, mintha szénszálas bevonattal rendelkezne. A könnyebb súly önmagában is hosszabb üzemidőt jelent, de az eszköz grafénakkumulátorral is rendelkezik. A Manchester Egyetem foglalkozik grafénakkumulátorok fejlesztésével, ők biztosították a Juno drón akkumulátorát is. A grafénalapú akkumulátorokkal egy okostelefon töltése néhány másodperc, míg egy elektromos autóé néhány perc. A grafén nemcsak az akkumulátorok gyorsabb újratöltését, nagyobb kapacitását biztosítja, de élettartamát is megnöveli. A grafén akkumulátorok akár a testhő vagy a nap által újratölthetők. A Manchester Egyetem ezenkívül kísérletezik a szél- vagy napenergia grafénakkumulátorokban való tárolásával is. ${ }^{33}$

\subsection{Drónok és földi eszközök összeköttetése}

A drónok bevethetők földi jármüvek hálózatával együtt. Olyan helyzetekben, amikor nem áll rendelkezésre infrastruktúra, a drónokat mobil infrastruktúra-elemként lehet telepíteni. A drón és az autó közötti kommunikáció eléri a három kilométert

\footnotetext{
Mohamed N. Boukoberine - Zhibin Zhou - M. Benbouzid: Power Supply Architectures for Drones - A Review. In IECON $2019-45^{\text {th }}$ Annual Conference of the IEEE Industrial Electronics Society. 2019. 5826-5831.

33 First Graphene Skinned UAV - JUNO. Flykit Blog, (é. n.).
} 
kevéssé beépített területen, és az 50\% szállítási sikerarányt 2,7 kilométeres hatótávolságon belül. Az UAV-k együttmúködhetnek egy adott hálózat földi jármúveivel is, lehetővé téve a közöttük lévő adatcsere javítását. A technika a jármú mozgékonysága miatt különbözik a földi állomásokkal való kommunikációtól. ${ }^{34} \mathrm{Az}$ egyes jármúvek közti kommunikációban reléfunkciót töltenek be, képesek az adatokat továbbítani akkor is, ha nincs közöttük közvetlen multihop-kapcsolat és a közvetlen jármü-jármủ kommunikáció nem lehetséges (például magas épületek, hegyek közötti terület). Az UAV-k és az autók közötti optimális kapcsolat érdekében meg kell találni az optimális helyet és magasságot az UAV-k elhelyezéséhez, hogy megfelelő jeleket tudjanak továbbítani a földi jármủvek felé. Törekvések zajlanak a hálózati kapacitás, illetve a hálózat élettartamának maximalizálása érdekében. ${ }^{35} \mathrm{~A}$ 2.2. alfejezetben említett, drón által hordozott miniatürizált 4G- vagy 5G-állomások nem csupán arra alkalmasak, hogy a drón irányítását lehetővé tegyék, hanem mobil állomásként lehetôvé teszik a vezeték nélküli kapcsolat létrejöttét olyan esetekben, ahol az állandó bázisállomás kiépítése nem lehetséges vagy nem gazdaságos. Ezenkívül sajnálatos módon, a hálózat telítődik, amikor erre valóban szükség van, például egy természeti katasztrófa vagy egy terrortámadás idején. A drónra szerelt mobil bázisállomásokat FANET-nek (flying ad-hoc network) nevezik. Két lehetőség is van a kivitelezésre. Az egyik, hogy vagy múhold, vagy egy földi állomás koordinátor bázisállomás-szerepet tölt be és a további állomásoknak ahhoz kell kapcsolódnia. Ennek hátránya, hogy minden bázisállomásnak a koordinátor hatótávolságán belül kell lennie. Másik módszer a felhordó hálózat (backhaul network) alkalmazása. A felhordó hálózat a széles sávú hálózat azon része, amely közvetlenül összekapcsolja a gerinchálózatot a hozzáférési hálózattal, és adatokat továbbít a globális hálózat irányába és irányából. Ennél a módszernél a bázisállomásoknak csak egy része kapcsolódik a felhordó hálózathoz, a többi bázisállomás pedig ezekhez csatlakozik. ${ }^{36}$ A multiszenzoros counter-UAV-alkalmazások jelentős hátránya, hogy a különböző szenzorokból származó információkat nem olvasztják össze eredmény elérése érdekében, az egyes rendszerelemektől függetlenül használják, hogy több korai figyelmeztetést küldjenek, amelyeket később egy ember megerősít. Több objektum felismerése és osztályozása, valamint a több objektum nyomon követése és az adatok egyesítése a legfontosabb feladat. Ezek a drónelhárító rendszerek jellemzően radarral, akusztikus vagy rádiófrekvenciás módon, optikai jelzavarással múködnek, vagy komplex rendszerként több módszert egyesítenek. E rendszerek célja, hogy

34 Seilendria A. Hadiwardoyo et al.: Experimental Characterization of UAV-to-Car Communications. Computer Networks, 136. (2018), 105-118.

35 Seilendria A. Hadiwardoyo et al.: Three Dimensional UAV Positioning for Dynamic UAV-to-Car Communications. Sensors, 20. (2020), 2. 356.

36 Margot Deruyck et al.: Emergency Ad-Hoc Networks by Using Drone Mounted Base Stations for a Disaster Scenario. In 2016 IEEE $12^{\text {th }}$ International Conference on Wireless and Mobile Computing, Networking and Communications (WiMob) 2016. 1-7. 
valamilyen módon úgy lépjenek interakcióba a behatoló drónnal, hogy azt leszállásra vagy pályájának módosítására kényszerítsék. ${ }^{37}$

\subsection{Képi adattovábbítás fejlesztésére vonatkozó kompetenciák}

A valós idejű, nagy felbontású képtovábbítás nélkülözhetetlen eleme a drón biztonságos navigációjának, és a nem hobbicélú repülések esetén a precíz küldetés-végrehajtásnak is. Egy behatoló személy észlelésénél néhány másodperc késés talán nem okoz jelentős problémát, de például egy nagyobb sebességú jármú eseténél igen. Az együttmúködő pilóta nélküli repülőgépek egyik legfontosabb megoldatlan kérdése a vezeték nélküli kommunikáció más együttmúködő repülőgépekkel és/ vagy a földdel. A legnagyobb kihívást a valós idejű videók nagy távolságra történő továbbítása jelenti, a titkosítást is beleértve a biztonság érdekében. A repülőszerkezetek közötti kommunikáció nehézségei közé tartozik az antennák megtalálása megfelelő (azaz valóban minden irányú) mintázattal és alacsony energiaigénnyel. Emellett nagy sávszélességű kommunikációra lehet szükség. ${ }^{38} \mathrm{~A}$ jelenlegi kereskedelemben kapható drónok azonban gyenge interferencia-gátló képességgel és jelentős késleltetéssel rendelkeznek, így a videó megbízhatósága nem garantálható. A hálózati képátvitel során pixelhozzáférés alapján történik a továbbítás, amire azonban nagy erőforrás-fogyasztás jellemző. A vezeték nélküli rendszerek kulcsfontosságúak a valós idejű képtovábbításban. Ezért nyilvános, 4G-mobilhálózaton alapuló mérési és irányítási hálózatot fejlesztettek ki. A rendszer mind a drón irányításában, mind a képátvitel tekintetében jelentős fejlődést biztosít. A képátvitel magában foglalja a drónról érkező felvételek fogadását és a feldolgozott képek feltöltését a vizualizációs rendszerbe. A valós idejü képfeldolgozás ugyancsak jelentős eleme a folyamatnak. A cél a megszerzett felvételek alapján egyedi ortofotók létrehozása, és a küldetés jellegétől függően akár objektumok felismerése is. A képfeldolgozás folyamata magában foglalja a georeferálást, ortofotók generálását és az objektumfelismerést. A valós idejű feldolgozásnak képesnek kell lennie gyorsan hozzárendelni a helyadatokat a felvételekhez, hogy az ortofotó elkészülhessen, és gyors, pontos algoritmus szükséges az objektumdetektáláshoz. A valós idejü továbbítást alacsony késleltetéssel segíti a képtömörítés és párhuzamos átvitel a vezeték nélküli hálózaton. ${ }^{39}$ Egy 2020-as tanulmány szerint két pMDDL2450 adatkapcsolat alkalmazása 2,4 GHz-en és a vevőoldalon lévő irányított antennát alkalmazó megoldás

37 Georgia Lykou - Dimitrios Moustakas - Dimitris Gritzalis: Defending Airports from UAS: A Survey on CyberAttacks and Counter-Drone Sensing Technologies. Sensors, 20. (2020), 12. 3537.

38 Allison Ryan et al.: An Overview of Emerging Results in Cooperative UAV Control. In $200443^{\text {rd }}$ IEEE Conference on Decision and Control (CDC) (IEEE Cat. No. 04CH37601) 2004. 602-607.

39 Jin Guo et al.: Design of Real-Time Video Transmission System for Drone Reliability. IOP Conference Series: Materials Science and Engineering, 790. (2020), 1. 012004; I. Jeon et al.: A Real-Time Drone Mapping Platform For Marine Surveillance. International Archives Of The Photogrammetry, Remote Sensing \& Spatial Information Sciences, XLII-2/ W13. (2019), 385-391. 
TÓTH Veronika Zsófia: Drónok és más eszközök közötti interakciók, valamint a képi adattovábbítás...

felhasználható a kamerával készített nagy felbontású képek valós idejű továbbítására UAV-n. ${ }^{40}$

\section{4. Összefoglalás}

A tanulmányban bemutattam a drónok különböző kommunikációs csatornáit és a képi továbbítás fejlesztésére vonatkozó kompetenciákat. Az irányító és a drón, a drón-drón és a drón - földi eszköz kommunikációjának megvalósításához eltérő technológiák szükségesek. A repülés precíz, megbízható kivitelezéséhez és a küldetések végrehajtásához alapvető fontosságú a megbízhatóan működő kommunikáció. Az 5G-hálózat bevezetése újabb mérföldkövet jelent a dróntechnológia tekintetében mind a hatótávolság növekedése, mind a képtovábbítás szempontjából. Az agyhullámok segítségével történő drónirányítás, az önszerveződő drónrajok alapvetően változtatják meg az eddig ismert dróntechnológiát.

\section{IRODALOMJEGYZÉK}

Balázs, Boldizsár - Gábor Vásárhelyi - Tamás Vicsek: Adaptive Leadership Overcomes Persistence-Responsivity Trade-Off in Flocking. Journal of the Royal Society Interface, 17. (2020), 167. 20190853. Online: https://doi.org/10.1098/rsif.2019.0853

Boukoberine, Mohamed N. - Zhibin Zhou - M. Benbouzid: Power Supply Architectures for Drones - A Review. In IECON $2019-45^{\text {th }}$ Annual Conference of the IEEE Industrial Electronics Society. 2019. 5826-5831. Online: https://doi.org/10.1109/IECON.2019.8927702

Burt, Peter - Jo Frew: Crossing a Line: The Use of Drones to Control Borders. Drone Wars UK, 2020. Campion, Mitch - Prakash Ranganathan - Saleh Faruque: A Review and Future Directions of UAV Swarm Communication Architectures. In 2018 IEEE International Conference on Electro/ Information Technology (EIT). 903-908. Online: https://doi.org/10.1109/EIT.2018.8500274

Cauchard, Jessica R. - Jane L. E - Kevin Y. Zhai - James A. Landay: Drone \& Me: An Exploration into Natural Human-Drone Interaction. In Proceedings of the 2015 ACM International Joint Conference on Pervasive and Ubiquitous Computing. 2015. 361-365. Online: https://doi. org $/ 10.1145 / 2750858.2805823$

Chen, Liqi - Zheng Huang - Zhenbang Liu - Dawei Liu - Xin Huang: 4G Network for Air-Ground Data Transmission: A Drone based Experiment. In 2018 IEEE International Conference on Industrial Internet (ICII) 2018. 167-168. Online: https://doi.org/10.1109/ICII.2018.00028

Deruyck, Margot - Jorg Wyckmans - Luc Martens - Wout Joseph: Emergency Ad-Hoc Networks by Using Drone Mounted Base Stations for a Disaster Scenario. In 2016 IEEE $12^{\text {th }}$ International Conference on Wireless and Mobile Computing, Networking and Communications (WiMob) 2016. 1-7. Online: https://doi.org/10.1109/WiMOB.2016.7763173

DJI transmission systems - Wi-Fi, OcuSync \& Lightbridge. Heliguy, 2018. augusztus 20. Online: www.heliguy.com/blogs/posts/dji-transmission-systems-wi-fi-ocusync-lightbridge

ELTE: Beszélgető drónrajok, összehangolt repülés (2018. július 18.). Online: www.elte.hu/content/ beszelgeto-dronrajok-osszehangolt-repules.t.17006

40 Vladan Papić et al.: High-Resolution Image Transmission from UAV to Ground Station for Search and Rescue Missions Planning. Applied Sciences, 11. (2021), 5. 2105. 
TÓTH Veronika Zsófia: Drónok és más eszközök közötti interakciók, valamint a képi adattovábbítás...

First Graphene Skinned UAV - JUNO. Flykit Blog, (é. n.). Online: https://blog.flykit.app/firstgraphene-skinned-uav-juno/

Fotouhi, Azade - Ming Ding - Mahbub Hassan: Dronecells: Improving 5G Spectral Efficiency Using Drone-Mounted Flying Base Stations. 2017. Online: https://arxiv.org/abs/1707.02041

Guirado, R. - J. C. Padró - A. Zoroa - J. Olivert - A. Bukva - P. Cavestany: StratoTrans: Unmanned Aerial System (UAS) 4G Communication Framework Applied on the Monitoring of Road Traffic and Linear Infrastructure. Drones, 5. (2021), 1. 10. Online: https://doi. org/10.3390/drones5010010

Guo, Jin - Xiaoyan Li - Zhigang Lv - Yongxia Yang - Liangliang Li: Design of real-time video transmission system for drone reliability. IOP Conference Series: Materials Science and Engineering, 790. (2020), 1. 012004. Online: https://doi.org/10.1088/1757-899X/790/1/012004

Hadiwardoyo, Seilendria A. - Carlos T. Calafate - Juan-Carlos Cano - Kirill Krinkin - Dmitry Klionskiy - Enrique Hernández-Orallo - Pietro Manzoni: Three Dimensional UAV Positioning for Dynamic UAV-to-Car Communications. Sensors, 20. (2020), 2. 356. Online: https:// doi.org/10.3390/s20020356

Hadiwardoyo, Seilendria A. - Enrique Hernández-Orallo - Carlos T. Calafate - Juan-Carlos Cano - Pietro Manzoni: Experimental Characterization of UAV-to-Car Communications. Computer Networks, 136. (2018), 105-118. Online: https://doi.org/10.1016/j. comnet.2018.03.002

Hell Péter: Drón-rendszerek biztonságos kommunikációja. Köztes-Európa, 8. (2016), 1-2. 169175. Online: http://acta.bibl.u-szeged.hu/48074/

Jeon, I. - S. Ham - J. Cheon - A. M. Klimkowska - H. Kim - K. Choi - I. Lee: A Real-Time Drone Mapping Platform For Marine Surveillance. International Archives Of The Photogrammetry, Remote Sensing \& Spatial Information Sciences, XLII-2/W13. (2019), 385-391. Online: https://doi.org/10.5194/isprs-archives-XLII-2-W13-385-2019

Jeong, Ji-Hoon - Dae-Hyeok Lee - Hyung-Ju Ahn - Seong-Whan Lee: Towards BrainComputer Interfaces for Drone Swarm Control. In $20208^{\text {th }}$ International Winter Conference on Brain-Computer Interface (BCI). 2020. 1-4. Online: https://doi.org/10.1109/ BCI48061.2020.9061646

Jiao, Ran - Zhaowei Wang - Ruihang Chu - Mingjie Dong - Yongfeng Rong - Wusheng Chou: An Intuitive End-to-End Human-UAV Interaction System for Field Exploration. Frontiers in Neurorobotics, 13, (2020), 117. Online: https://doi.org/10.3389/fnbot.2019.00117

Li, Bin - Zesong Fei - Yan Zhang: UAV Communications for 5G and Beyond: Recent Advances and Future Trends. IEEE Internet of Things Journal, 6. (2018), 2. 2241-2263. Online: https:// doi.org/10.1109/JIOT.2018.2887086

Li, Kai - Ni Wei - Xin Wang - Ren Ping Liu - Salil S. Kanhere - Sanjay Jha: Energy-Efficient Cooperative Relaying for Unmanned Aerial Vehicles. IEEE Transactions on Mobile Computing, 15. (2015), 6. 1377-1386. Online: https://doi.org/10.1109/TMC.2015.2467381

Li, Xiaohui: Deployment of Drone Base Stations for Cellular Communication without Apriori User Distribution Information. In 2018 37 th Chinese Control Conference (CCC) 2018. 72747281. Online: https://doi.org/10.1109/TMC.2015.2467381

Lonzetta, Angela M. - Peter Cope - Joseph Campbell - Bassam J. Mohd - Thaier Hayajneh: Security Vulnerabilities in Bluetooth Technology as Used in IoT. Journal of Sensor and Actuator Networks, 7. (2018), 3. 28. Online: https://doi.org/10.3390/jsan7030028

Lyu, Jiangbin - Yong Zeng - Rui Zhang - Teng Joon Lim: Placement Optimization of UAVMounted Mobile Base Stations. IEEE Communications Letters, 21. (2017), 3. 604-607. Online: https://doi.org/10.1109/LCOMM.2016.2633248

Lykou, Georgia - Dimitrios Moustakas - Dimitris Gritzalis: Defending Airports from UAS: A Survey on Cyber-Attacks and Counter-Drone Sensing Technologies. Sensors, 20. (2020), 12. 3537. Online: https://doi.org/10.3390/s20123537

Marin, Iuliana - Missar J. H. Al-Battbootti - Nicolae Goga: Drone Control Based on Mental Commands and Facial Expressions. In $202012^{\text {th }}$ International Conference on Electronics, 
TÓTH Veronika Zsófia: Drónok és más eszközök közötti interakciók, valamint a képi adattovábbítás...

Computers and Artificial Intelligence (ECAI) 2020. 1-4. Online: https://doi.org/10.1109/ ECAI50035.2020.9223246

Muzaffar, Raheeb - Christian Raffelsberger - Aymen Fakhreddine - José López Luque - Driton Emini - Christian Bettstetter: First Experiments with a 5G-Connected Drone. In Proceedings of the $6^{\text {th }}$ ACM Workshop on Micro Aerial Vehicle Networks, Systems, and Applications, 2020. 1-5. Online: https://doi.org/10.1145/3396864.3400304

Nawaz, Haque - Husnain M. Ali - Asif A. Laghari: UAV Communication Networks Issues: A Review. Archives of Computational Methods in Engineering, 28. (2021). 1349-1369. Online: https://doi.org/10.1007/s11831-020-09418-0

Oliver, Dan: 5G drones: everything you need to know. 5Gradar, 2021. augusztus 24. Online: www.5gradar.com/news/5g-drones-take-to-the-skies

Papić, Vladan - Petar Šolić - Ante Milan - Sven Gotovac - Miljenko Polić: High-Resolution Image Transmission from UAV to Ground Station for Search and Rescue Missions Planning. Applied Sciences, 11. (2021), 5. 2105. Online: https://doi.org/10.3390/app11052105

Qazi, Sameer - Ali S. Siddiqui - Asim I. Wagan: UAV Based Real Time Video Surveillance over 4G LTE. In 2015 International Conference on Open Source Systems \& Technologies (ICOSST) 2015. 141-145. Online: https://doi.org/10.1109/ICOSST.2015.7396417

Ryan, Allison - Marco Zennaro - Adam Howell - Raja Sengupta - J. Karl Hedrick: An Overview of Emerging Results in Cooperative UAV Control. In $200443^{\text {rd }}$ IEEE Conference on Decision and Control (CDC) (IEEE Cat. No. 04CH37601) 2004. 602-607. Online: https://doi. org/10.1109/CDC.2004.1428700

Russon, Mary-Ann: Nokia and EE trial mobile base stations floating on drones to revolutionise rural 4G coverage. International Business Times, 2016. augusztus 15. Online: www. ibtimes.co.uk/nokia-ee-trial-mobile-base-stations-floating-drones-revolutionise-rural-4gcoverage-1575795

Tezza, Dante - Marvin Andujar: The State-of-the-Art of Human-Drone Interaction: A Survey. IEEE Access, 7. (2019), 167438-167454. Online: https://doi.org/10.1109/ACCESS.2019.2953900

Vásárhelyi, Gábor - C. Virágh - G. Somorjai - N. Tarcai - T. Szörényi - T. Nepusz - T. Vicsek: Outdoor Flocking and Formation Flight with Autonomous Aerial Robots. In 2014 IEEE/RSJ International Conference on Intelligent Robots and Systems 2014. 3866-3873. Online: https:// doi.org/10.1109/IROS.2014.6943105

Víz alatti drónt is bevetnének a határvédelemben. Privátbankár, 2019. augusztus 27. Online: https://privatbankar.hu/cikkek/makro/vizalatti-dront-vezeto-nelkuli-terepjarotvetnenek-be-a-hatarvedelemben-327972.html

Zulkifley, Muhammad A. - Mehran Behjati - Rosdiadee Nordin - Mohamad S. Zakaria: Mobile Network Performance and Technical Feasibility of LTE-Powered Unmanned Aerial Vehicle. Sensors, 21. (2021), 8. 2848. Online: https://doi.org/10.3390/s21082848

\section{Jogforrás}

Commission Implementing Regulation (EU) 2019/947 of 24 May 2019 on the rules and procedures for the operation of unmanned aircraft. C/2019/3824. Online: https://eur-lex.europa. eu/eli/reg_impl/2019/947/oj 


\section{ABSTRACT}

Competences for Developing Interactions between Drones and Other Devices, as well as Image Transmission

Zsófia Veronika TÓTH

Unmanned aerial vehicles (drones) allow data to be collected in areas and times that are still inaccessible to traditional remote sensing platforms. Due to technical advances, their scope is expanding and the devices are being specified. The main limiting factors of the application are the image transmission and the interaction between the drone and other devices (e.g. dronecontroller relationship, drone-drone communication). The aim of this study is to present the current state of these technologies and possible future development directions.

Keywords: drone, image data transmission, interaction 